\title{
Model Pengelolaan Tanah Wakaf Di Kota Semarang
}

\author{
Yasin Arief S. ${ }^{*} \&$ Tali Tulab ${ }^{* *}$ \\ Universitas Islam Sultan Agung (UNISSULA), Semarang \\ Email: yasinarief@unissula.ac.id; talitulab@unissula.ac.id
}

\begin{abstract}
Waqf in Indonesia is one of the Islamic institutions related to the welfare of the ummah and has long been institutionalized. The problems arising from some of the wakaf practices in the community are not only about the implementation of wakaf, but also in the management of wakaf land in accordance with the principles of sharia. The implementation of wakaf in Semarang City is similar to the management in other areas. Wakaf trends in the community are still around mosques, schools and tombs as objects of waqf. The results of research indicate that the practice of waqf in KUA is still waqf about the land. data in the field indicates, that allotment of musholla as much as $49 \%$. While the mosque as much as $27 \%$. Schools and pesantren are $13 \%$ and $3 \%$. Tombs of $3 \%$ and other social institutions as much as $5 \%$. As for the condition of wakaf land, as many as $79 \%$ of existing wakaf land has been certified. Meanwhile, $21 \%$ is only limited to the deed of pledge of waqf.
\end{abstract}

Keywords: Model, Management, Waqf, Semarang

\section{Abstrak}

Wakaf di Indonesia merupakan salah satu lembaga Islam yang erat kaitannya dengan kesejahteraan umat dan sudah lama melembaga.

* Dosen Program Studi Ahwal Syakhshiyyah, Jurusan Syariah, Fakultas Agama Islam, Universitas Islam Sultan Agung (UNISSULA), Semarang

** Pengasuh Pondok Pesantren Taqwal Ilah Semarang, Dosen Program Studi Ahwal Syakhshiyyah, Jurusan Syariah, Fakultas Agama Islam, Universitas Islam Sultan Agung (UNISSULA), Semarang 
Perwakafan merupakan salah satu bentuk ketentuan Islam dalam mengakomodir hubungan antar sesama manusia demi mencapai sebuah kesejahteraan bersama. Permasalahan yang timbul dari beberapa praktik wakaf di masyarakat tidak hanya seputar pelaksanaan wakafnya, melainkan juga dalam hal pengelolaan tanah wakaf agar sesuai dengan prinsip-prinsip syariah. Pelaksanaan wakaf di Kota Semarang sama dengan pengelolaan di daerah lain. Tren wakaf yang ada di masyarakat masih seputar masjid, sekolah dan makam sebagai obyek perwakafan. Hasil penelusuran melalui penelitian ini menunjukkan bahwa praktik wakaf yang ada di KUA masih merupakan praktik wakaf lama yakni seputar tanah. Dari total tanah wakaf, dapat disimpulkan bahwa peruntukan musholla sebanyak $49 \%$. Sedangkan masjid sebanyak $27 \%$. Sekolah dan pesantren sebanyak 13\% dan 3\%. Makam sebanyak $3 \%$ dan lembaga sosial lain sebanyak $5 \%$. Sedangkan untuk kondisi tanah wakaf, sebanyak $79 \%$ dari tanah wakaf yang ada telah memiliki sertifikat. Sedangkan $21 \%$ baru sebatas akta ikrar wakaf.

Kata Kunci: Model, Pengelolaan, Wakaf, Semarang

\section{Pendahuluan}

07 akaf di Indonesia merupakan salah satu lembaga Islam yang erat kaitannya dengan kesejahteraan umat dan sudah lama melembaga. Wakaf telah lama menjadi perhatian pemerintah di Indonesia sejak masa kesultanan hingga saat ini. Perwakafan merupakan salah satu bentuk ketentuan Islam dalam mengakomodir hubungan antar sesama manusia demi mencapai sebuah kesejahteraan bersama. Di samping juga merupakan sarana untuk menjaga hubungan baik dengan Allah SWT. Wakaf sebagai salah satu bentuk dari ibadah telah dikenal oleh manusia sejak zaman dahulu terbentuk dari tatanan kehidupan bermasyarakat di muka bumi. Wakaf juga sebagai konsep sosial yang memiliki dimensi ibadah, dan juga disebut sebagai amal jariyah. Dimana pahala yang didapat oleh wakif (orang yang mewakafkan) akan selalu mengalir selama harta tersebut masih ada dan bermanfaat. Seperti menyediakan pelayanan umum yang dibutuhkan oleh manusia secara keseluruhan atau kebanyakan anggota masyarakat.

Ulul Albab: Jurnal Studi dan Penelitian Hukum Islam 
Praktik perwakafan yang telah lama dilaksanakan di Indonesia ialah wakaf tanah. Sebagian besar tanah wakaf di Indonesia digunakan untuk rumah ibadah, perguruan tinggi Islam dan lembaga-lembaga keagamaan Islam lainnya. ${ }^{1}$ Permasalahan yang timbul dari beberapa praktik wakaf di masyarakat tidak hanya seputar pelaksanaan wakafnya, melainkan juga dalam hal pengelolaan tanah wakaf agar sesuai dengan prinsip-prinsip syariah. Selain itu, wakaf sebagai suatu institusi keagamaan yang memiliki dualisme fungsi sekaligus yakni fungsi ibadah dan fungsi muamalah, sudah seharusnya kemanfaatannya dapat berdampak nyata terhadap kesejahteraan masyarakat. Penelitian yang dilakukan oleh Ahmad Furqon tentang model pembiayaan wakaf tanah produktif menemukan fakta banyaknya model pembiayaan tanah wakaf dengan cara memproduktifkan aset wakaf. ${ }^{2}$

Semarang sebagai salah satu kota besar di Indonesia dan ibukota provinsi Jawa Tengah, memiliki banyak tanah wakaf. Penelitian tentang bandha wakaf Masjid Agung Semarang menghasilkan kesimpulan salah satunya tentang konflik berkepanjangan tentang tanah wakaf bandha masjid yang selama bertahun-tahun mengalami nasib tidak jelas dan terombangambing kepemilikannya. Menurut keputusan Menteri Agama no. 12 tahun 1980, bahwa harta yang dimiliki Masjid Agung Semarang sebanyak 129 ha yang terletak menyebar di Semarang, Demak dan Kendal. ${ }^{3}$ Hingga pada akhirnya, pada tahun 1999, tanah wakaf bandha masjid dapat kembali menjadi milik Masjid Agung Semarang.

1 Departemen Agama RI, Lembaga Pengelola Wakaf (Nazhir), (Jakarta: Depag RI, 2004), 1

2 Ahmad Furqon, "Model-Model Pembiayaan Wakaf Tanah Produktif", Economica: Jurnal Ekonomi Islam, Vol. V, No. 1, (Semarang: UIN Walisongo, 2014), $1-20$

3 Agus Fathuddin Yusuf, Melacak Banda Masjid Yang Hilang, Cet. I, (Semarang: Aneka Ilmu, 2000), 30 
Salah satu dari tanah yang kembali menjadi milik Masjid Agung Semarang adalah tanah yang sekarang dimanfaatkan untuk SPBU (Stasiun Pengisian Bahan bakar Umum) yang terletak di kelurahan Sawah Besar Gayamsari Semarang. Tanah yang notabene termasuk tanah wakaf tersebut dimanfaatkan secara produktif yang hasilnya digunakan untuk memakmurkan Masjid Agung Semarang. Model pengelolaan tanah wakaf produktif semacam inilah yang dapat dikembangkan dan dirasakan manfaatnya dalam peningkatan kesejahteraan umat. Atas dasar inilah, peneliti tertarik untuk meneliti lebih dalam tentang pelaksanaan pengelolaan tanah wakaf di Kota Semarang. Penelitian ini difokuskan pada wilayah Kota Semarang.

\section{Metode Penelitian}

Penelitian ini akan menggunakan metode kualitatif, karena studi ini bermaksud mengetahui keadaan sesuatu mengenai apa, bagaimana, sejauh mana, berapa banyak, dan sebagainya. Dengan menggambarkan data hasil penelitian dengan kata-kata atau kalimat yang dipisah menurut katagori dan dianalisis untuk memperoleh kesimpulan. ${ }^{4}$ Metode kualitatif akan digunakan untuk mengetahui pelaksanaan pengelolaan tanah wakaf di kota Semarang. Penelitian ini tentu melibatkan interaksi dengan masyarakat sekitar, di mana setiap perilaku individu akan dilihat dalam konteks kolektif sebagai representasi sebuah sistem. Lokasi penelitian ini adalah kota Semarang Provinsi Jawa Tengah.

Strategi penelitian yang diterapkan adalah studi kasuistik yakni peristiwa yang terjadi pada satu tempat atau beberapa tempat yang telah ditentukan dan memilki gejala kemapanan serupa antara satu tempat dengan lainnya.

4 Suharsimi Arikunto, Prosedur Penelitian Suatu Pendekatan Praktek, (Jakarta: Rineke Cipta, 1992), 10

Ulul Albab: Jurnal Studi dan Penelitian Hukum Islam 
Model Pengelolaan Tanah Wakaf .... $\mid 67$

Penentuan informan dilakukan secara sengaja berdasarkan karakteristik yang diinginkan dan mengacu pada keterwakilan aspek persoalan. Beberapa informan yang diperlukan antara lain:

a) Informan dari pegawai KUA setempat.

b) Informan dari beberapa nadzir di wilayah setempat.

Dalam penelitian ini ada dua jenis data yang diperlukan untuk mengungkap fenomena sosial yang menjadi fokus kajian. Pertama, data yang digali dari lapangan secara langsung melalui teknik observasi partisipatif dan teknik wawancara mendalam. Informasi yang diperoleh akan didokumentasikan dalam bentuk catatan tertulis atau perekaman dengan bantuan MP4 recorder, sebagi hasil kegiatan melihat, mendengar dan bertanya terhadap para informan. Data lapangan yang diperoleh dari observasi antara lain: kondisi obyektif lokasi penelitian dan pelaksanaan pengelolaan tanah wakaf di lokasi penelitian. Data yang diperoleh melalui wawancara mendalam berpedoman pada fokus masalah yang ditetapkan. Kedua, data sekunder yang diperoleh dengan menggunakan teknik dokumentasi yang berupa, majalah, arsip, dokumen pribadi, dokumen resmi dan dan berbagai literatur yang relevan dengan masalah penelitian.

Sebagaimana dalam judul penelitian ini bahwa yang akan dijadikan sebagai populasi dalam penelitian ini ialah seluruh Kepala KUA yang berada di kota Semarang. Jika melihat jumlah KUA yang ada di Kota Semarang yakni sebanyak 16 kecamatan yang tersebar dalam ruang lingkup yang cukup luas yakni kota Semarang, maka sampel yang dapat diambil dari keseluruhan polulasi antara lain $10 \%-15 \%$ atau $20-25 \%$ atau lebih, tergantung setidak-tidaknya:

a) Kemampuan peneliti dilihat dari segi waktu, tenaga dan dana.

b) Sempit luasnya wilayah pengamatan dari setiap subyek, karena hal ini menyangkut banyak sedikitnya data 
c) Besar kecilnya resiko yang di tanggung oleh peneliti. Untuk penelitian yang resikonya besar, tentu saja jika sampel lebih besar maka hasilnya akan lebih baik. ${ }^{5}$

Oleh karena itulah, teknik pengambilan sampel yang akan peneliti gunakan ialah dengan cara proporsionate sampling yaitu sebesar $25 \%$ dari populasi. Sehingga dapat diinformasikan bahwa jumlah sampel dalam penelitian ini ialah 25\% dari 16 KUA yakni 4 KUA. 4 KUA tersebut antara lain KUA Pedurungan, KUA Gayamsari, KUA Banyumanik dan KUA Genuk.

Untuk menganalisis data kualitatif yang akan digunakan metode interaktif yang bertumpu pada tiga jalur, yaitu: reduksi data, penyajian data dan penarikan kesimpulan. Secara rinci tahapan analisis ini berpedoman pada hal-hal berikut:

a) Reduksi data, sebagai bentuk analisis yang mempertajam, mengarahkan, menggolongkan, membuang yang dipandang tidak perlu serta mengorganisasikan data. Adapun cara yang ditempuh: meringkas data, mengkode, menelusuri tema.

b) Penyajian data, yaitu suatu aktifitas pengelompokan yang tersusun sehingga memberikan kemungkinan adanya kemudahan penarikan kesimpulan dan pengambilan keputusan bertindak. Bentuk-bentuk penyajian data yang dilakukan yaitu: teks naratif dalam bentuk catatan lapangan, pembuatan matrik, grafik, jaringan dan baganbagan.

c) Penarikan kesimpulan, yaitu aktifitas yang bermula dari awal penelitian melalui sebuah pendekatan spesifik tentang pengartian dan pemaknaan terhadap benda-benda, catatancatatan keteraturan pola, konfigurasi yang mungkin terjadi, alur sebab akibat maupun proposisi. Kesimpulan yang dihasilkan juga diverifikasikan dengann cara: pemikiran

${ }^{5}$ Ibid., hlm. 107

Ulul Albab: Jurnal Studi dan Penelitian Hukum Islam 
ulang atas data lapangan selama penulisan, melakukan tinjauan ulang terhadap catatan lapangan, diskusi dengan orang-orang yang dianggap sebagai sumber informasi yang memiliki kemampuan di bidang penelitian maupun pemahaman tentang fenomena sosial. Langkah selanjutnya diselesaikan dengan menempatkan salinan temuan tersebut berdasarkan seperangkat data yang ada dalam suatu deskripsi serta interpretasi yang dilakukan oleh peneliti untuk menjaga agar tidak terdapat bias atau pengaruh adanya stereotipe masyarakat pada umumnya.

\section{Wakaf di Indonesia}

Pranata wakaf merupakan sebuah pranata yang berasal dari hukum Islam. Oleh karena itu, apabila berbicara tentang masalah perwakafan, tidak mungkin melepaskan pembicaraan tentang konsepsi wakaf menurut hukum Islam. Akan tetapi, dalam Islam tidak ada konsep yang tunggal tentang wakaf, karena apabila mendalami tentang wakaf, akan dihadapkan pada pendapat.

Perkataan waqf menjadi wakaf dalam bahasa Indonesia berasal dari kata kerja bahasa Arab waqafa yaqifu waqfan yang berarti ragu-ragu, berhenti, meletakkan, memahami, mencegah, menahan, mengatakan, memperlihatkan, meletakkan, memperhatikan, mengabdi dan tetap berdiri. ${ }^{6}$ Sebagai kata benda, kata wakaf semakna dengan kata al-habs dengan arti menahan. ${ }^{7}$ Pada intinya, kata wakaf berarti menahan, mencegah atau melarang dan diam. Dikatakan menahan karena wakaf ditahan dari kerusakan, penjualan dan semua tindakan yang tidak sesuai dengan tujuan wakaf.

${ }^{6}$ Ahmad Warson Munawwir, Kamus Al Munawwir, (Surabaya: Pustaka Progressif, 1997), 1576

7 Abdul Ghofur Anshori, Hukum dan Praktik Perwakafan di Indonesia, (Yogyakarta: Pilar Media, 2005), 7 
Sejarah perwakafan di Indonesia telah dimulai sejak masa kesultanan. Banyak bukti ditemukan bahwa pada masa kesultanan telah dilakukan ibadah wakaf, khususnya terlihat pada beberapa bangunan seperti masjid, madrasah, dan juga komplek makam. Beberapa bukti sejarah yang dapat ditemukan antara lain:

a) Masjid Al Falah Jambi yang merupakan tanah Sultan Thaha Saifuddin.

b) Masjid Kauman Cirebon, wakaf dari Sunan Gunung Jati

c) Masjid Demak, wakaf Sultan Fatah

d) Masjid Menara Kudus, wakaf dari Sunan Muria

e) Masjid Janik Pengkalan, wakaf Sultan Abdul Qadirun

f) Masjid Agung Semarang wakaf dari Pangeran Pandanaran

g) Masjid Ampel Surabaya wakaf dari Raden Rahmat Sunan Ampel

h) serta masih banyak lagi. ${ }^{8}$

Pada masa kolonial Belanda wakaf juga telah menjadi perhatian pemerintah Belanda. Buktinya ialah dikeluarkannya beberapa surat edaran yang didalamnya berisi beberapa ketentuan baik yang berkaitan langsung dengan wakaf ataupun tidak. Pada intinya, Pemerintah Kolonial Belanda saat itu berupaya mencampuri aktivitas umat Islam, salah satunya melalui wakaf.

Upaya campur tangan Belanda terhadap dunia perwakafan umat Islam menimbulkan reaksi penentangan dari umat Islam karena pada praktiknya, orang yang hendak berwakaf diharuskan untuk izin kepada Bupati. Mereka berpendapat bahwa perwakafan adalah suatu tindakan hukum privat sehingga sah atau tidaknya tidak perlu izin dari pemerintah bahkan pemerintah tidak perlu campur tangan. ${ }^{9}$

${ }^{8}$ Munir SA., Wakaf Tanah Menurut Islam dan Perkembangannya di Indonesia, (Pekanbaru: UIR Press, 1991 ), 140-143

${ }_{9}$ Imam Suhadi, Hukum Wakaf di Indonesia, (Yogyakarta: Dua Dimensi, 1985), 6-7

Ulul Albab: Jurnal Studi dan Penelitian Hukum Islam 
Dalam perkembangannya, perhatian pemerintah Indonesia terhadap dunia perwakafan terus meningkat menyusul diperbaikinya regulasi-regulasi tentang wakaf baik melalui peraturan pemerintah, maupun peraturan menteri agama, atau menteri yang lain. Hingga pada akhirnya, muncullah Kompilasi Hukum Islam yang dirumuskan oleh Ulama bersama pakar hukum Islam Indonesia. Sedangkan untuk penguatnyam diterbitkan pula Inpres No. 1 Tahun 1991. Khusus permasalahan wakaf dalam KHI difokuskan pada buku III yang isinya meliputi:

a) BAB I berisi tentang pasal 215 yang memuat ketentuan umum, arti wakaf, ikrar wakaf, benda wakaf, nadzir, dan pejabat pembuat akte ikrar wakaf (PPAIW)

b) BAB II berisi 7 pasal (pasal 216-222) yang memuat tentang ketentuan fungsim unsur-unsur dan syarat wakaf.

c) BAB III berisi 2 pasal (pasal 223 dan 224) yang berisi tentang tata cara wakaf dan pendaftaran benda wakaf.

d) BAB IV 3 pasal (pasal 224-226) yang memuat tentang perubahan, penyelesaian perselisihan dan pengawasan benda wakaf.

e) BAB V berisi pasal 228 dan 229 tentang ketentuan peralihan dan penutup.

Paradigma wakaf di Indonesia pada saat ini menuju ke arah kemajuan yang signifikan seiring dengan keberadaan wakaf yang telah merambah kepada jenis wakaf dengan pengelolaan produktif. Wakaf produktif yaitu wakaf yang pokok barangnya dipergunakan untuk kegiatan produksi dan hasilnya diberikan sesuai dengan tujuan wakaf. ${ }^{10}$ Salah satu bentuk nyata yang menggunakan model produktif dalam pengelolaan tanah wakaf ialah tanah wakaf milik Masjid Agung Semarang yang digunakan untuk SPBU (Stasiun Pengisian

${ }^{10}$ Mundzir Qahaf, Manajemen Wakaf Produktif, terj. Muhyidin Masrida, Penyunting: Abdurrahman Kasdi, Cet. 1, (Jakarta: Khalifa, 2004), 162 
Bahan bakar Umum) yang terletak di kelurahan Sawah Besar Gayamsari Semarang. Saat ini, tanah wakaf tersebut menjadi tanah wakaf yang sangat produktif yang menghasilkan keuntungan materiil yang tidak sedikit yang diharapkan mampu mensejahterakan dan memakmurkan Masjid Agung Semarang serta membantu pihak-pihak yang memerlukan bantuan seperti fakir miskin maupun kegiatan-kegiatan lainnya yang bersifat sosial dan keagamaan sesuai dengan tujuan wakaf.

\section{Pengelolaan Tanah Wakaf di Kota Semarang}

Pelaksanaan wakaf di kota Semarang secara umum dapat dikategorikan dalam kondisi baik. Hal ini dikarenakan praktik pengelolaan wakaf telah berlangsung lama di masyarakat serta ditopang dengan aturan perundang-undangan yang sangat membantu dan komitmen perwakilan dari Kementrian Agama yang dalam hal ini dijalankan oleh Kantor Urusan Agama (KUA) yang ada di setiap kecamatan. Komitmen tersebut berupa pelaksanaan fungsi pengawasan serta bantuan administratif lainnya yang tercantum dalam Peraturan Pemerintah yakni Keputusan Menteri Agama RI Nomor 517 Tahun 2001, khususnya pasal 1,2 dan 3.

Pelaksanaan wakaf di kota Semarang sebagaimana yang terjadi di kebanyakan daerah di Indonesia yakni telah dipraktikkan oleh masyarakat sejak lama. Wakaf telah lama melembaga hingga sampai saat ini, telah dibuat prosedur dan mekanisme sedemikian rupa demi kepentingan pendataan dan administrasi.

Keserupaan pelaksanaan wakaf di Semarang tidak hanya dalam hal waktu keberlangsungan, namun juga dalam hal jenis perwakafan. Hingga saat ini, pelaksanaan wakaf yang diakomodir oleh KUA di kota Semarang baru berupa wakaf tanah, bukan yang lain. ${ }^{11}$

${ }^{11}$ Wawancara dengan KUA Pedurungan tanggal 12 November 2015

Ulul Albab: Jurnal Studi dan Penelitian Hukum Islam 
Model Pengelolaan Tanah Wakaf .... 73

Hasil pengamatan peneliti terhadap pelaksanaan wakaf di kota Semarang, membuahkan hasil berupa data tanah wakaf yang berlangsung melalui KUA di 4 kecamatan yakni Pedurungan, Gayamsari, Banyumanik dan Genuk. Berikut perinciannya:

\section{a) Kecamatan Pedurungan}

Pelaksanaan wakaf di kecamatan Pedurungan dikelola oleh KUA setempat dengan mekanisme sebagaimana yang telah disebutkan sebelumnya. Total tanah wakaf yang terdata di Kecamatan Pedurungan ialah sebanyak 233 lokasi dengan luas 93,132 $\mathrm{m}^{2}$. Dari jumlah tersebut, yang telah bersertifikat sebanyak 175 lokasi dengan total 75,078 $\mathrm{m}^{2}$ atau sekitar $78 \%$.

Dari total tanah wakaf yang terdata di Kecamatan Pedurungan tahun 2014, di antaranya ada yang telah bersertifikat dan ada juga yang baru sebatas Akta Ikrar Wakaf (belum sertifikat). Yang baru sebatas akta ikrar wakaf yaitu total sebanyak 58 lokasi dengan luas total $18,059 \mathrm{~m}^{2}$ atau sekitar $22 \%$.

Selain itu, dari sekian jumlah tanah wakaf yang terdata di KUA Pedurungan tahun 2014, penggunaan atau pemanfaatan tanah wakaf di Pedurungan berkisar pada masjid, mushola, sekolah atau madrasah, makam, pesantren dan lembaga sosial lain. Masjid dan mushola merupakan peruntukan tanah wakaf yang paling banyak di Pedurungan yaitu sebanyak 163 lokasi dengan luas total $50,256 \mathrm{~m}^{2}$.

\section{b) Kecamatan Gayamsari}

Kecamatan Gayamsari terletak di sebelah timur kota Semarang berdekatan dengan Genuk, Pedurungan dan Semarang Timur. Meski kecamatan Gayamsari memiliki luas relatif kecil yakni hanya $6,18 \mathrm{~km}^{2}$ jika dibandingkan dengan kecamatan-kecamatan lain di Semarang, namun jumlah tanah wakafnya pada tahun 2014 cukup banyak yakni hingga 64 tanah wakaf dengan luas $415,948 \mathrm{~m}^{2}$.

Keseluruhan tanah wakaf yang ada di kecamatan Gayamsari berjumlah 64 lokasi dengan total luas 41.59 ha. Dari 
jumlah tersebut 54 lokasi (85\%) telah memiliki sertifikat wakaf sedangkan sisanya yakni 10 lokasi baru mendapatkan akta ikrar wakaf. Sedangkan penggunaan wakaf, mayoritas digunakan untuk mushola yakni 26 lokasi. Untuk masjid 18 lokasi dan sisanya untuk pesantren, sekolah dan lembaga sosial lainnya.

\section{c) Kecamatan Banyumanik}

Kecamatan Banyumanik termasuk kecamatan di Kota Semarang yang memiliki wilayah cukup luas yakni 25,69 $\mathrm{Km}^{2}$. Jumlah total tanah wakaf yang terdata di KUA kecamatan Banyumanik sekitar 115 lokasi dengan luas total 3,69 ha. Dari total lokasi dan luas tanah wakaf tersebut yang telah memiliki sertifikat adalah sebanyak 106 lokasi dengan luas sekitar 3,5 ha. Sedangkan sisanya belum memiliki sertifikat wakaf.

Mengenai peruntukan wakaf, dari total lokasi wakaf yang terdata di KUA kecamatan Banyumanik, didominasi oleh Musholla yakni sebanyak 54 lokasi. Sedangkan masjid sebanyak 51 lokasi. Sisanya untuk sekolah, pesantren, dan lembaga sosial lainnya.

\section{d) Kecamatan Genuk}

Kecamatan Genuk merupakan kecamatan yang letaknya di sebelah timur kota Semarang yang memiliki luas hingga 27,39 $\mathrm{Km}^{2}$. Jumlah total tanah wakaf yang terdata di KUA kecamatan Genuk sekitar 207 lokasi dengan luas total 9,60 ha. Dari total keseluruhan tanah wakaf, yang telah terwujud dalam bentuk sertifikat sebanyak 148 lokasi dengan luas total 7,8 ha. Atau sekitar $70 \%$ dari keseluruhan. Sedangkan sebanyak 63 lokasi dengan luas 1,84 ha. belum memiliki sertifikat atau hanya sebatas akta ikrar wakaf.

Jika dirinci, dalam masalah penggunaan tanah wakaf di kecamatan Genuk, tidak sama seperti kecamatan lain yakni hanya digunakan untuk masjid, mushola, sekolah atau madrasah dan makam minus pesantren dan lembaga sosial lainnya. Kebanyakan penggunaannya ialah untuk mushola yakni sebanyak 123 lokasi dengan rincian 88 telah tersertifikasi

Ulul Albab: Jurnal Studi dan Penelitian Hukum Islam 
Model Pengelolaan Tanah Wakaf .... 75

dan sisanya belum. Kemudian di urutan kedua, tanah wakaf di Genuk digunakan untuk sekolah dengan total sebanyak 38 lokasi (18 telah tersertifikasi dan 20 belum). Selanjutnya untuk masjid sebanyak 30 lokasi dengan 23 tersertifikasi dan sisanya belum. Kemudian berupa makam sebanyak 12 dalam kondisi tersertifikasi semua.

Pelaksanaan wakaf di Kota Semarang sama dengan pengelolaan di daerah lain. Tren wakaf yang ada di masyarakat masih seputar masjid, sekolah dan makam sebagai obyek perwakafan. Hasil penelusuran melalui penelitian ini menunjukkan bahwa tren wakaf masyarakat tidak mengalami perubahan dengan masa lampau.

Hal ini jika dilakukan analisa lebih dalam, dapat diketahui bahwa pelaksanaan wakaf di KUA hingga saat ini masih berkisar wakaf tanah. Dari hasil penelusuran peneliti ke 4 KUA di kota Semarang, masing-masing mengatakan bahwa praktik wakaf yang ada di KUA masih merupakan praktik wakaf lama yakni seputar tanah. Artinya, belum ada wakaf dengan menggunakan obyek lain semisal wakaf tunai. Kecenderungan masyarakat menurut peneliti, untuk melaksanakan wakaf tunai ialah dilaksanakan di lembaga keuangan syariah baik bank maupun non-bank. menurut peneliti yang menyebabkan hal tersebut salah satunya ialah kurangnya sosialisasi oleh kemenag maupun KUA tentang wakaf tunai di KUA.

Kondisi keseluruhan tanah wakaf di kota Semarang dari hasil penelitian di 4 KUA yang ada, menghasilkan bahwa kondisi tanah wakaf, sebanyak $79 \%$ dari tanah wakaf yang ada telah memiliki sertifikat. Sedangkan $21 \%$ baru sebatas akta ikrar wakaf.

Selanjutnya mengenai pengelolaan tanah wakaf di Kota Semarang. Jika mengacu pada UU No 41 Tahun 2004 maka KUA di setiap kecamatan berfungsi sebagai pejabat pembuat akta ikrar wakaf yang diberi wewenang oleh Menteri. Oleh karena itulah, kewenangan KUA dalam hal yang berkaitan dengan 
tanah wakaf hanya sebatas pendataan administratif saja serta sebagai pejabat pembuat akta ikrar wakaf. Selebihnya, pengelolaan tanah wakaf selanjutnya dikuasakan penuh kepada nadzir.

Peneliti menilai tentang permasalahan administratif wakaf, dalam hal ini yang telah dilakukan oleh KUA yang ada di kota Semarang relatif baik. Artinya, telah sesuai dengan ketentuan yang ada dalam UU. Hasil penelusuran peneliti, bahwa ketika ada orang yang hendak wakaf, maka segera menghubungi KUA setempat untuk mendapatkan beberapa formulir antara lain Akta Ikrar Wakaf yang terdiri dari formulir W.1, W.2 dan W.5 (Pengesahan Nadzir). ${ }^{12}$

Selanjutnya, dalam hal pengelolaan tanah wakaf oleh nadzir, amanah dari UU no 41 Tahun 2004 antara lain:

a) Nazhir wajib mengelola dan mengembangkan harta benda wakaf sesuai dengan tujuan, fungsi, dan peruntukannya.(Pasal 42)

b) Pengelolaan dan pengembangan harta benda wakaf oleh Nazhir sebagaimana dimaksud dalam Pasal 42 dilaksanakan sesuai dengan prinsip syariah.

c) Pengelolaan dan pengembangan harta benda wakaf sebagaimana dimaksud pada ayat (1) dilakukan secara produktif.

d) Dalam hal pengelolaan dan pengembangan harta benda wakaf yang dimaksud pada ayat (1) diperlukan penjamin, maka digunakan lembaga penjamin syariah.

e) Dalam mengelola dan mengembangkan harta benda wakaf, Nazhir dilarang melakukan perubahan peruntukan harta benda wakaf kecuali atas dasar izin tertulis dari Badan Wakaf Indonesia.(Pasal 44)

Jika melihat ketentuan-ketentuan tersebut, maka dapat ditarik kesimpulan bahwa pengelolaan tanah wakaf harus sesuai

12 Wawancara dengan KUA Pedurungan tanggal 12 November 2015

Ulul Albab: Jurnal Studi dan Penelitian Hukum Islam 
dengan peruntukan tanah wakaf tersebut. Melihat pelaksanaan wakaf di kota Semarang yang sebelumnya telah peneliti ungkapkan bahwa masih hanya berkisar obyek berupa tanah, maka pengelolaannya oleh nadzir juga harus disesuaikan dengan peruntukan awal.

Data perwakafan yang peneliti dapatkan dari 4 kecamatan menghasilkan bahwa peruntukan tanah wakaf antara lain

a) Mushola total sebanyak 299 lokasi

b) Masjid sebanyak 166 lokasi

c) Sekolah atau Madrasah sebanyak 85 lokasi

d) Pesantren sebanyak 15 lokasi

e) Makam sebanyak 20 lokasi

f) Dan lembaga sosial lain sebanyak 29 lokasi.

Rinciannya adalah sebagaimana tertera dalam tabel 1 .

\begin{tabular}{|l|c|c|c|c|l|}
\hline KNTUR & Pedurungan & Gayamsari & Banyumanik & Genuk & TOTAL \\
\hline MUSHOLA & 96 & 54 & 26 & 123 & 299 \\
\hline MASJID & 67 & 51 & 18 & 30 & 166 \\
\hline SEKOLAH & 33 & 9 & 45 & 38 & 85 \\
\hline PESANTREN & 12 & 1 & 2 & - & 15 \\
\hline MAKAM & 8 & - & - & 12 & 20 \\
\hline $\begin{array}{l}\text { SOSIAL } \\
\text { LAIN }\end{array}$ & 17 & - & 8 & 4 & 29 \\
\hline
\end{tabular}

Tabel. 1.

Analisis peruntukan tanah wakaf Sumber: Hasil Olah Data Wawancara, 2016 
Jika dilihat dari data tersebut, dapat dianalisa menggunakan prosentase bahwa total tanah wakaf yang ada di 4 kecamatan tersebut ialah 614. Peruntukan musholla sebanyak $49 \%$. Sedangkan masjid sebanyak $27 \%$. Sekolah dan pesantren sebanyak $13 \%$ dan 3\%. Makam sebanyak $3 \%$ dan lembaga sosial lain sebanyak $5 \%$.

Pasal 43 UU No 41 tahun 2004 menyatakan bahwa pengelolaan dan pengembangan harta benda wakaf sebagaimana dimaksud pada ayat (1) dilakukan secara produktif. Penjelasan makna produktif dalam pasal tersebut ialah pengelolaan dan pengembangan harta benda wakaf dilakukan secara produktif antara lain dengan cara pengumpulan, investasi, penanaman modal, produksi, kemitraan, perdagangan, agrobisnis, pertambangan, perindustrian, pengembangan teknologi, pembangunan gedung, apartemen, rumah susun, pasar swalayan, pertokoan, perkantoran, sarana pendidikan ataupun sarana kesehatan, dan usaha-usaha yang tidak bertentangan dengan syariah. ${ }^{13}$

Maka menurut peneliti, dari enam peruntukan wakaf yang terlaksana di kota Semarang, hanya sekolah dan pesantren saja yang dapat dikategorikan sebagai pengelolaan produktif terhadap tanah wakaf. Kalaupun dapat ditambahkan, maka peruntukan berupa lembaga sosial lain, asalkan berorientasi pada pengelolaan harta wakaf secara produktif dapat juga dikategorikan sebagai wakaf produktif. Maka dapat ditarik kesimpulan bahwa model pengelolaan tanah wakaf di Kota Semarang dengan cara produktif baru berjalan sebanyak $31 \%$. Sisanya $69 \%$ masih berkisar pada pengelolaan tanah wakaf non produktif berupa masjid, mushola dan makam.

${ }^{13}$ Penjelasan pasal 43 UU No 41 tahun 2004

Ulul Albab: Jurnal Studi dan Penelitian Hukum Islam 
\begin{tabular}{l|l} 
Model Pengelolaan Tanah Wakaf .... & 79
\end{tabular}

\section{Penutup}

Pelaksanaan wakaf di Kota Semarang sama dengan pengelolaan di daerah lain. Tren wakaf yang ada di masyarakat masih seputar masjid, sekolah dan makam sebagai obyek perwakafan. Hasil penelusuran melalui penelitian ini menunjukkan bahwa praktik wakaf yang ada di KUA masih merupakan praktik wakaf lama yakni seputar tanah. Dari total tanah wakaf, dapat disimpulkan bahwa peruntukan musholla sebanyak $49 \%$. Sedangkan masjid sebanyak $27 \%$. Sekolah dan pesantren sebanyak $13 \%$ dan 3\%. Makam sebanyak 3\% dan lembaga sosial lain sebanyak 5\%. Sedangkan untuk kondisi tanah wakaf, sebanyak $79 \%$ dari tanah wakaf yang ada telah memiliki sertifikat. Sedangkan $21 \%$ baru sebatas akta ikrar wakaf.

UU No 41 tahun 2004 tentang wakaf menyatakan bahwa pengelolaan tanah wakaf harus sesuai dengan peruntukan tanah wakaf. Pelaksanaan wakaf di kota Semarang yang hanya berkisar obyek berupa tanah, maka pengelolaannya oleh nadzir juga harus disesuaikan dengan peruntukan awal. Dari enam peruntukan wakaf yang terlaksana di kota Semarang, hanya sekolah dan pesantren saja yang dapat dikategorikan sebagai pengelolaan produktif terhadap tanah wakaf. Kalaupun dapat ditambahkan, maka peruntukan berupa lembaga sosial lain, asalkan berorientasi pada pengelolaan harta wakaf secara produktif dapat juga dikategorikan sebagai wakaf produktif. Maka dapat ditarik kesimpulan bahwa model pengelolaan tanah wakaf di Kota Semarang dengan cara produktif baru berjalan sebanyak $31 \%$. Sisanya $69 \%$ masih berkisar pada pengelolaan tanah wakaf non produktif berupa masjid, mushola dan makam.

Sebagai tindak lanjut dari kesimpulan yang telah dipaparkan, berikut peneliti paparkan saran yaitu agar pemerintah melalui Kementrian Agama serta Kantor Urusan Agama hendaknya banyak melakukan sosialisasi tentang wakaf kepada masyarakat. Hal ini dilakukan agar praktik pelaksanaan 
80 Yasin Arief S. \& Tali Tulab

wakaf semakin baik dan berkembang, menuju ke arah pengelolaan wakaf produktif sehingga kemanfaatan wakaf terhadap kesejahteraan masyarakat akan optimal.

\section{Daftar Pustaka}

Anshori, Abdul Ghofur. 2005. Hukum dan Praktik Perwakafan di Indonesia, Yogyakarta: Pilar Media

Arikunto, Suharsimi. 1992. Prosedur Penelitian Suatu Pendekatan Praktek, Jakarta: Rineke Cipta

Departemen Agama RI. 2004. Lembaga Pengelola Wakaf (Nazhir), Jakarta: Depag RI

Munawwir, Ahmad Warson. 1997. Kamus Al Munawwir, Surabaya: Pustaka Progressif

Munir SA. 1991. Wakaf Tanah Menurut Islam dan Perkembangannya di Indonesia, Pekanbaru: UIR Press

Qahaf, Mundzir. 2004. Manajemen Wakaf Produktif, terj. Muhyidin Masrida, Penyunting: Abdurrahman Kasdi, Cet. 1, Jakarta: Khalifa

Suhadi, Imam. 1985. Hukum Wakaf di Indonesia, Yogyakarta: Dua Dimensi

UU RI No 41 tahun 2004 Tentang Wakaf

Yusuf, Agus Fathuddin. 2000. Melacak Banda Masjid Yang Hilang, Cet. I, Semarang: Aneka Ilmu

Furqon, Ahmad. 2014. 'Model-Model Pembiayaan Wakaf Tanah Produktif', Economica: Jurnal Ekonomi Islam, Vol. V. No. 1. Semarang: UIN Walisongo. 1-20

Ulul Albab: Jurnal Studi dan Penelitian Hukum Islam 